\title{
Biochemistry and metabolism of fats
}

By R. P. Cook, Biochemistry Department, Queen's College (University of St. Andrews), Dundee

The topic 'biochemistry and metabolism of fats' covers a wide field and, although this communication is concerned mainly with triglycerides, a general account of other lipids or 'fats' is given because they are all interconnected. Only the distribution and transport of fat within the body will be considered; the absorption of fat is dealt with in articles in the British Medical Bulletin (Popják, 1958) and in Page (1958). For our purposes we may consider that the 'typical' Western world man eats about I $00 \mathrm{~g}$ fat/day, absorbing at least $95 \%$ and obtaining about $35 \%$ of his total calories from it. Table I summarizes typical values for the content of water and lipid and the distribution of lipid in blood plasma and in some body tissues.

Table r. Typical lipid composition of body tissues on a fresh-weight basis (The composite values collected from the literature are approximate)

\begin{tabular}{|c|c|c|c|c|c|c|}
\hline & & & & & Nerve & tissue \\
\hline & $\begin{array}{l}\text { Blood } \\
\text { plasma }\end{array}$ & Liver & $\begin{array}{l}\text { Adipose } \\
\text { tissue }\end{array}$ & Muscle & $\begin{array}{l}\text { White } \\
\text { matter }\end{array}$ & $\begin{array}{c}\text { Grey } \\
\text { matter }\end{array}$ \\
\hline Water $(\%)$ & 90 & 75 & I 5 & 75 & 70 & 80 \\
\hline 'Lipid' (\%) & 0.5 & 5 & 80 & 4 & 20 & 7 \\
\hline & Distribut & of lipid & percenta & of total) & & \\
\hline $\begin{array}{l}\text { Neutral fat } \\
\text { (mainly triglyceride) }\end{array}$ & I 5 & 25 & 95 & 40 & Slight & Slight \\
\hline Phospholipids & 30 & 66 & c. 3 & c. 12 & 40 & 50 \\
\hline Sphingolipids & c. 2 & c. 3 & $?$ & $?$ & 25 & 40 \\
\hline Total sterol & 40 & 5 & c. 0.3 & 2 & 25 & IO \\
\hline $\begin{array}{l}\text { Sterol ester (as percentage } \\
\text { of total sterol) }\end{array}$ & 66 & c. 20 & c. 20 & c. 30 & 0 & 0 \\
\hline
\end{tabular}

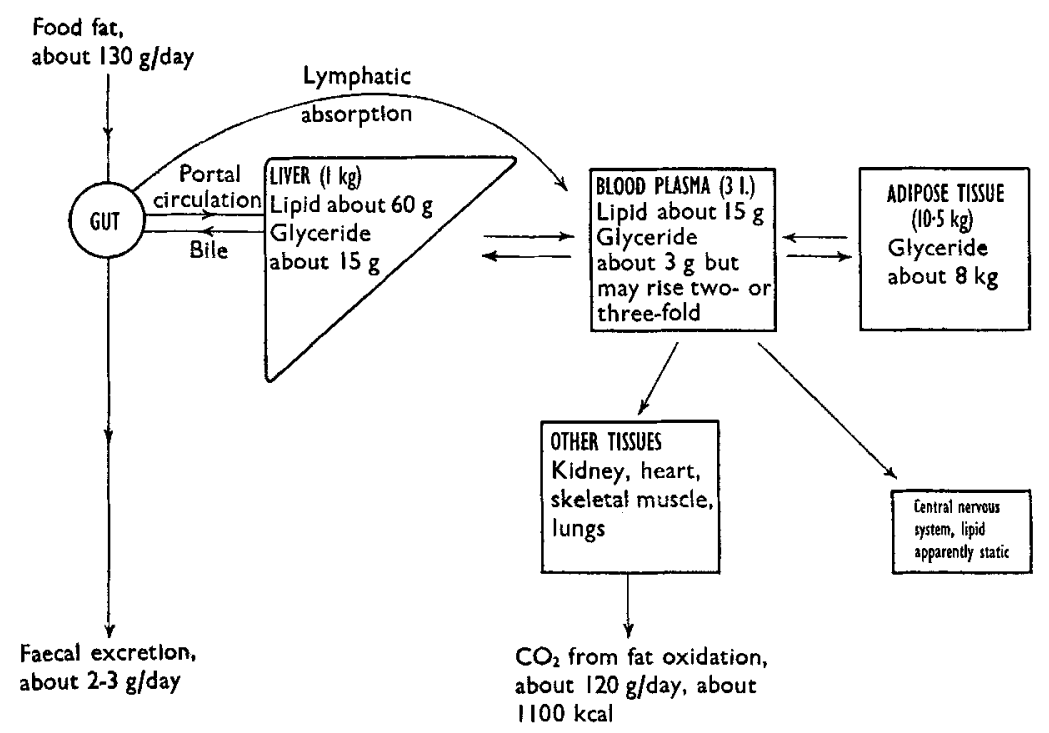

Fig. I. The circulation of lipids (as glycerides mainly) in a 'normal' $70 \mathrm{~kg}$ Western man. Typical values are given for the weights of the major tissues. 


\section{Pathways of lipid transport and metabolism in the body}

Fig. I shows diagrammatically the main pathways for lipid transport in the body. Nature of the lipid circulating in the blood plasma (reviewed by Frederickson \& Gordon, 1958). In the postabsorptive state the plasma is transparent, but after a fatty meal it becomes lipaemic owing to the presence of chylomicrons. In due course the plasma clears and the amount of lipid decreases to its fasting value. Part of this 'clearing' effect is due to lipoprotein lipase produced by the tissues (e.g. heart muscle, adipose tissue) which acts mainly on the triglyceride moieties (reviewed by Korn, 1958). In addition to chylomicron transport, lipid is carried as lipoproteins and as fatty acids united to albumin (Table 2 ). Metabolic products such as acetoacetic and $\beta$-hydroxybutyric acids (about $0.5 \mathrm{mg} / \mathrm{ro0} \mathrm{ml}$ ) and a small amount of acetic acid are present normally in human blood plasma. Typical distributions of fatty acids and their patterns are shown in Table 3; the amount and distribution of glyceride fatty acids are considerably influenced by diet, the fatty acids in the phospholipids and cholesteryl esters are also affected but not so markedly.

Table 2. Plasma chylomicrons and lipoproteins (from Oncley, 1958; Dole, 1958; Gurd, 1960)

\begin{tabular}{|c|c|c|}
\hline & $\begin{array}{c}\text { Amount } \\
(\mathrm{g} / 100 \mathrm{ml})\end{array}$ & $\begin{array}{c}\text { Composition (as } \mathrm{g} / \mathrm{ro0} \mathrm{g}) \\
\text { and remarks }\end{array}$ \\
\hline Chylomicrons & $\begin{array}{l}\text { Variable with } \\
\text { diet }\end{array}$ & $\begin{array}{l}\text { Protein } 1-2 \text {, glyceride } 85 \text {, phospholipid } 7 \text {, } \\
\text { cholesterol } 5\end{array}$ \\
\hline $\begin{array}{l}\text { Low density } \\
(d 0.98-1 \cdot 03) \text { or } \\
\beta \text {-lipoproteins }\end{array}$ & $c .0 .5$ & $\begin{array}{l}\text { Protein 20, glyceride 10, phospholipid } 20 \text {, } \\
\text { cholesterol, mainly ester, about } 40 \text {. There are } \\
\text { two classes at least. These are the main forms } \\
\text { in which cholesterol and its esters are carried }\end{array}$ \\
\hline $\begin{array}{l}\text { High density } \\
\quad\left(d \mathrm{I} \cdot 09^{-1} \cdot 14\right) \text { or } \\
\quad \alpha-\text { lipoproteins }\end{array}$ & $c .0 \cdot 5$ & $\begin{array}{l}\text { Protein about } 55 \text {, glyceride about } 7 \text {, phospho- } \\
\text { lipid about } 30 \text {, cholesterol about 1o. Two } \\
\text { classes at least are found }\end{array}$ \\
\hline Albumin & $\begin{array}{l}4 \text { (containing } \\
\text { about } 0 \cdot 5 \mathrm{~m} \text { - } \\
\text { equiv. of fatty } \\
\text { acids) }\end{array}$ & $\begin{array}{l}\text { The unesterified or free fatty acids are carried } \\
\text { bound to albumin. }\end{array}$ \\
\hline
\end{tabular}

Table 3. Typical distribution of fatty acids in lipid fractions of human blood plasma (from Hilditch \& Fasperson, 1959)

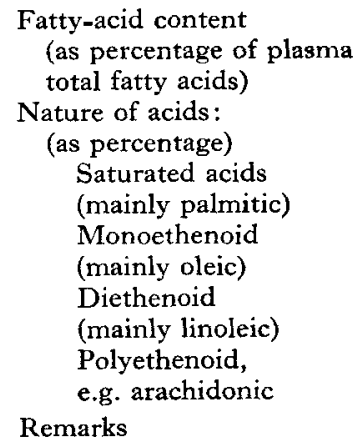

$\begin{array}{cccc}\begin{array}{c}\text { Glycerides } \\ 25\end{array} & \begin{array}{c}\text { Phospholipids } \\ 40\end{array} & \begin{array}{c}\text { Cholesteryl } \\ \text { esters }\end{array} & \begin{array}{c}\text { Albumin- } \\ \text { bound }\end{array} \\ & 30 & 5 \\ 25 & 40 & 15 & \begin{array}{l}\text { Palmitic } \\ \text { and stearic }\end{array} \\ 35 & 25 & 25 & \begin{array}{l}\text { Oleic } \\ 5-45\end{array} \\ 20 & 50 & \text { Linoleic } \\ \text { about } 5 & 10 & 5-10 & \end{array}$

Variable with diet
Vary with diet but
not so markedly as do glycerides
These acids form $80 \%$ of total acids present 
Adipose tissue (reviewed by Kekwick, 1960 ). This tissue is an important factor in the homeostasis of fat in the body. Glycerides (and probably other lipids) are deposited in, or removed from, the adipose tissue. The albumin-bound fatty acids probably arise mainly from it. The fatty-acid composition of the glycerides is considered as characteristic of a particular species but it can be altered by dietary fat (cf. 'hard' and 'soft' pork).

Fatty-acid oxidation (reviewed by Lynen, I955; Lehninger, 1958; and Green $\&$ Gibson, I960). This process has been most studied in the liver but does occur in other tissues (see below). The enzymes responsible are located in the mitochondria and need for their functioning a number of cofactors, such as adenosine triphosphate (ATP), diphosphopyridine nucleotide (DPN), flavineadeninedinucleotide (FAD) and coenzyme A (CoA).

Tissues, such as liver, cardiac muscle and kidney, oxidize fatty acids to acetyl CoA, which is then 'caught up' in the citric-acid cycle and, in conjunction with carbohydrate metabolites, is metabolized to $\mathrm{CO}_{2}$ and water, yielding energy. 'This process is thus 'direct' utilization of fatty acids. In the liver, acetyl CoA can also condense to form acetoacetyl CoA from which $\beta$-hydroxybutyryl CoA is formed by hydrogenation. From these arise the 'acetone bodies' which can be oxidized by extrahepatic tissues and this pathway represents 'indirect' utilization of the fatty acids.

\section{Interrelationships of lipid metabolism}

Fat metabolism in a whole organism is a complex system with constantly changing patterns. Fig. 2 shows some of the suggested interrelationships between the types of

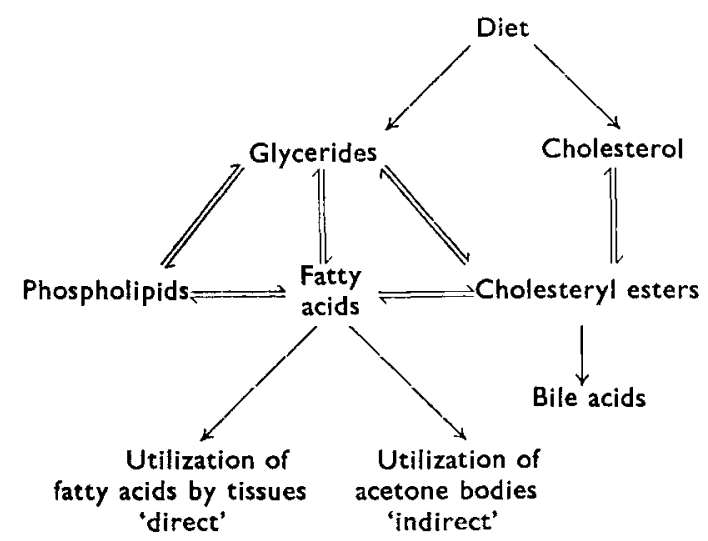

Fig. 2. The interrelation of the main types of lipid, their dependence on dietary factors and their metabolic fates.

lipid and their dependence on dietary factors. Hormonal factors are also important but cannot be discussed here. The level of plasma cholesterol is influenced by the nature of the dietary fat and is discussed elsewhere in this symposium (Oliver, I96I). The increasing interest in lipid metabolism will, we hope, help us to decide, not only 
from the level of plasma cholesterol but also from other criteria, whether butter is a 'bad' fat and safflower-seed oil a 'good' one.

\title{
REFERENCES
}

Dole, V. (1958). In Chemistry of Lipides as Related to Atherosclerosis, p. I89. [I. H. Page, editor.] Springfield, Ill.: Charles C. Thomas.

Frederickson, D. S. \& Gordon, R. S. Jt. (1958). Physiol. Rev. 38, 585.

Green, D. E. \& Gibson, D. M. (1960). In Metabolic Pathways, Vol. 1, p. 301. [D. M. Greenberg, editor.] New York and London: Academic Press Inc.

Gurd, F. R. N. (r960). In Lipide Chemistry, Chapter 9. [D. J. Hanahan, editor.] New York: John Wiley \& Sons Inc.

Hilditch, T. P. \& Jasperson, H. (1959). Lipids in Relation to Arterial Disease. Liverpool: J. Bibby \& Sons Ltd.

Kekwick, A. ( 1960$)$. Brit. med. f. ii, 407.

Korn, E. D. (1 958). In Chemistry of Lipides as Related to Atherosclerosis, p. 169. [I. H. Page, editor.] Springfield, Ill.: Charles C. Thomas.

Lehninger, A. L. (1958). In Chemistry of Lipides as Related to Atherosclerosis, p. 265. [I. H. Page, editor.] Springfield, IIl.: Charles C. Thomas.

Lynen, F. (1955). Annu. Rev. Biochem. 24, 653.

Oliver, M. F. (I961). Proc. Nutr. Soc. 20, 169.

Oncley, J. L. (1958). In Chemistry of Lipides as Related to Atherosclerosis, p. I I4. [I. H. Page, editor.] Springfield, Ill.: Charles C. Thomas.

Page, I. H. (editor) (1958). Chemistry of Lipides as Related to Atherosclerosis. Springfield, Ill.: Charles C. Thomas.

Popják, G. (editor) (1958). Metabolism of Lipids. Brit. med. Bull. 14, no. 3, pp. 197-273.

\section{The chemistry of the animal and vegetable fats in relation to their utilization and industrial processing}

\author{
By A. Crossley, Unilever Research Laboratory, Port Sunlight, Cheshire
}

In making a comparison of the chemical properties of the animal and vegetable fats it is worth first considering which fats are of the most interest in the nutritional field. Table I gives data for the most important of the fat-containing foods consumed in the United Kingdom, and Table 2 shows the proportions of animal, vegetable and marine fats. Butter, margarine, and oils and fats consumed as such, are included as

Table I. Consumption of fats in the U.K. during 1957 (derived from Devine $\&$ Williams, 196 I)

\begin{tabular}{|c|c|c|c|c|}
\hline \multirow[b]{2}{*}{ Source of fat } & \multicolumn{2}{|c|}{ Amount/head } & \multirow{2}{*}{$\begin{array}{l}\text { Percentage } \\
\text { of total }\end{array}$} & \\
\hline & $\mathrm{lb}$ & $\mathrm{kg}$ & & \\
\hline Butter & I $4 \cdot 5$ & $6 \cdot 6$ & I3 & \\
\hline Margarine & 12.9 & $5 \cdot 8$ & I I & fats \\
\hline Other animal and vegetable fats & $20 \cdot 0$ & $9 \cdot I$ & I 8 & \\
\hline Milk, cheese & 14.9 & $6 \cdot 7$ & 13 & \\
\hline Meat & $37 \cdot 6$ & $17 \cdot 1$ & 33 & \\
\hline Fish & I.9 & 0.9 & 2 & 'Invisible' \\
\hline Eggs & $3 \cdot 3$ & $1 \cdot 5$ & 3 & fats \\
\hline Cereals and nuts & $4 \cdot 7$ & 2. I & 4 & \\
\hline Cocoa products & $3 \cdot 0$ & $I \cdot 4$ & 3 & \\
\hline Total & 112.8 & $5 I \cdot 2$ & & \\
\hline
\end{tabular}

